\title{
Characterization of Humus in Soil and It's Relation with Physical and Physic-Chemical Properties of Soil Under Long - Term Effect of Integrated Nutrient Management in Sorghum Wheat Cropping System
}

\author{
A. L. Dhamak ${ }^{*}$, S. L.Waikar and S. S. Shilewant \\ Department of Soil Science and Agriculture Chemistry, Vasantrao Naik Marathwada Krishi \\ Vidyapeeth, Parbhani, 431401, Maharashtra, India \\ *Corresponding author
}

\section{A B S T R A C T}

K e y w o r d s
Integrated nutrient
management,
Humus fraction,
Humic Acid, Fulvic
Acid, Organic
carbon, Total
carbon

\section{Keywords}

Integrated nutrien anagement, Humic Acid, Fulvic , Tota

Article Info

Accepted: Available Online: October 2020

\section{Introduction}

Sorghum-wheat is one of the cropping sequences which is gaining popularity under intensive cultivation on Vertisol in the state of Maharashtra. The cereal-cereal cropping sequence has high requirements for major nutrients and may adversely affect crop production on long run and hence, adequate nutrient management for this cropping sequence needs attention for sustainable soil productivity. Chemical fertilizers/organic manures alone cannot sustain the desired levels of crop production under continuous farming. Integrated nutrient management is very essential which not only sustains high crop production over the years but also improves soil health and ensures safer environment. Green revolution has brought about spectacular increases in food grain production. But, after initial success, situation today has changed in quest of short-term gains without due consideration of long term sustainality. Integration of chemical and 
organic sources and their efficient management have shown promising results not only in sustaining the productivity but also in maintaining in soil health (Vijay Shankar Babu et al., 2007).

The soil organic material broadly divided into two groups, non-humic substances and humic substances. Non-humic substances include various nitrogenous and non nitrogenous compounds like proteins and their degradation products, carbohydrates, fats, waxes, resins, pigments and numerous low molecular weight compounds. On the other hand, humic substances are not related to any of the existing known groups of organic chemistry and form a large part of total reserves of humus $(80-90 \%)$. These are yellow or brown to black coloured, acidic, poly disperse substances of relatively high molecular weight (Stevenson, 1982). Based on solubility, the humic substances are broadly divided into three classes. (a) Humic acid (alkali soluble and acid insoluble). (b) Fulvic acid (acid and alkali soluble) and (c) Humin (insoluble in both acid and alkali). (Naga Madhuri et al., 2013). Humic acid and fulvic acids are the highly reactive natural polymers of humus have predominantly carbon, oxygen, hydrogen and nitrogen; with the former three contributing around $95 \%$ to their composition.

The molecular weights of humic acid and fulvic acid were found to range from a few hundreds to few thousands. These macromolecules are highly reactive, probably because of the amounts and types of functional groups present, specially the oxygen containing ones. Most the these functional groups are acidic due to the presence of dissociable hydroxyl groups and thus contribute to the cation exchange capacity of the organic matter (Challa et al., 1985). Long-term experiments are the primary source of information to determine the effect of cropping systems on soil quality attributes like humin, humic acid, fulvic acid content, HA:FA ratio, organic carbon, inorganic carbon and total organic carbon content that are most sensitive to management inputs and to ascertain the impact of longterm use of integrated nutrient on these attributes (Kharche et al., 2013).

\section{Materials and Methods}

The Long-Term Fertilization Experiment on sorghum-wheat crop rotation was established in deep black soils of (Typic Haplustert) survey No. 124 of Parbhani block of Central farm, Vasantrao Naik Marathwada Krish Vidyapeeth, Parbhani since 1983. The experiment laid out randomized block design with set of fourteen treatments (Table 1) since 31 years and replicated thrice. The experimental soil is clayey in texture, calcareous in nature, moderately alkaline in reaction, low in available nitrogen, medium in phosphorous and high in potassium content. The soil analysis was carried out at the end of every crop season by standard methods of analysis and the changes in various soil properties as influenced by INM were studied. Organic carbon and inorganic carbon determined by Heated dichromate method for TOC Total organic carbon determined by dry combustion method, TOC as described by (Technical manual USETA, 2001).

Humus Fractions: HuminHumic acid (HA)andFulvic acid (FA) drawn by Stevanson's, 1982 procedure (Fourty gm sample of acid-washed (0.1 N HCL) soil was placed into an 8-oz polyethylene centrifuge bottle, add $200 \mathrm{ml}$ of $0.5 \mathrm{~N} \mathrm{NaOH}$ solution and stopped the bottle tightly with a rubber stopper. Mixture was shaked for $12 \mathrm{hrs}$ on a mechanical shaker. The sides of the bottle were washed with distilled water and centrifuged the mixture. Decanted off the dark colored supernatant liquid, filtered it through 
glass wool to remove suspended plant material and adjusted the $\mathrm{pH}$ of solution to about 1.0 with conc. HCL. Add an additional $200 \mathrm{ml}$ of $0.5 \mathrm{~N} \mathrm{NaOH}$ solution to the soil, again shaked the mixture for 1 hour and repeated the centrifuging and decanting procedures. Dispersed residue in $200 \mathrm{ml}$ of distilled water, centrifuged the mixture and add the supernatant liquid to the previous extracts. Adjust the $\mathrm{pH}$ of the resulting solution to 1.0 with conc. HCL, and allow the HA to settle. Siphon off the excess supernatant liquid (FA) from the acidified extract, transferred the remainder of the suspension to an 8-oz polyethylene bottle and centrifuged off the HA. Redissolved the HA in $0.5 \mathrm{~N} \mathrm{NaOH}$ solution, reprecipitated it by adjusting the $\mathrm{pH}$ of solution to 1.0 with concentrated HCL and then centrifuged out the HA. In each case, add the supernatant liquid to the original acid filtrate. Repeat the purification procedure a second time and then washed the HA precipitate with distilled water until it is free of chlorides. Dried the HA by freeze-drying and grinded it to a brown powder.).

\section{Results and Discussion}

\section{Effect on Humus Fraction}

Humic substances have the capacity to interact with metal ions, which makes them important agents for specifications and mobility of metals in soils. Characteristics of humus fractions have proven useful in interpretation of organic matter dynamics in soil. A extensive literature exists on characterization of humic matter and on binding of metals to humic matter mainly concerning laboratory experiments with humic or fulvic fractions purified from water or soil.

\section{Humin}

In this study Humin content of humus was varied between 34.70 to 50.40 percent in $0-15$ cm depth and 29.60 to 43.20 in $15-30 \mathrm{~cm}$ depth. The lower and higher values were recorded in $\mathrm{T}_{6}$ and $\mathrm{T}_{1}$ treatments respectively (Table 2). From the results presented here also indicated that humin content of humus constitute bulk of organic matter. It was noticed that application of NPK through fertilizers gave higher values of humin than treatment constituted organic manures with chemical inorganic fertilizers. The results presented above revealed that humin in inorganic fertilizers applied plots was more than plots supplied with organic + inorganic. The fraction that cannot be extracted from soil by dilute alkali is humin. Further it does not appear as a separate entity. The humin shows very strong bondings with inorganic soil colloids, hence more values of humin were recorded in the present study. Malewar (1995) also reviewed Vidharbha soils for their fractions and reported humin is a dominant fraction. At the $15-30 \mathrm{~cm}$ depth the humin content varied from $\mathrm{T}_{1}(43.20 \%)$ to treatment $\mathrm{T}_{6}(31.30 \%)$ the maximum value of humin is recorded in $\mathrm{T}_{6}$ treatment while minimum value was recorded in treatment $\mathrm{T}_{6}$. Gathalaet. al. (2007) noticed that reduction in humin content in subsurface layer due to form fractionation of humus into another fraction. These results coincide with the results of Naphade (1999) and Sangeeta (2015).

\section{Humic acid}

The result indicated that, humic acid content in soil was significantly affected under different treatment combinations of organic manures and inorganic fertilizers to soil media supporting sorghum-wheat cropping. It was ranged 26.60 to $34.40 \%$ in $0-15 \mathrm{~cm}$ depth and 24.20 to $32.50 \%$ in $15-30 \mathrm{~cm}$ depth. Overall effect of application of inorganic fertilizers (Treatment $T_{1}$ to $T_{5}$ ) shows low humic acid fraction values, while treatment $T_{6}$ 
to $\mathrm{T}_{11}$ where inorganic fertilizers applied in combination with organic manure shown higher values of humic acid. The humic acid content was less in subsurface soil as compared to surface soil. Significantly highest value of humic acid was noted in 50 percent $\mathrm{N}$ through FYM and 50 percent NPK through inorganic fertilizers, and lowest in control. Waikaret.al. (2004) in long-term field experiment found that humic acid (HA) content significantly increased due to the application of organic and inorganic fertilizer as compared to inorganic fertilizer alone in Typic Haplusterts. Naphade (1999)and Nguyen et al., (2010) also recorded similar results.

Table.1 Treatment Details

\begin{tabular}{|c|c|c|}
\hline \multirow[t]{2}{*}{ Treatments } & \multicolumn{2}{|c|}{ Treatments } \\
\hline & Kharif & Rabi \\
\hline$T_{1}$ & Control & Control \\
\hline $\mathbf{T}_{2}$ & $\begin{array}{l}50 \% \text { recommended (40:20:20) NPK kg } \\
\text { ha }^{-1} \text { through fertilizer }\end{array}$ & $\begin{array}{l}50 \% \text { recommended (60:30:30) NPK kg } \\
\text { ha }{ }^{-1} \text { through fertilizer }\end{array}$ \\
\hline $\mathbf{T}_{\mathbf{3}}$ & $\begin{array}{l}50 \% \text { recommended (40:20:20) NPK kg } \\
\text { ha }^{-1} \text { through fertilizer }\end{array}$ & $\begin{array}{l}100 \% \text { recommended (120:60:60) NPK } \\
\mathrm{kg} \mathrm{ha}^{-1} \text { through fertilizer }\end{array}$ \\
\hline $\mathbf{T}_{4}$ & $\begin{array}{l}75 \% \text { recommended (60:30:30) NPK kg } \\
\text { ha }^{-1} \text { through fertilizer }\end{array}$ & $\begin{array}{l}75 \% \text { recommended (90:45:45) NPK kg } \\
\text { ha }^{-1} \text { through fertilizer }\end{array}$ \\
\hline $\mathbf{T}_{5}$ & $\begin{array}{l}100 \% \text { recommended (80:40:40) NPK kg } \\
\text { ha }^{-1} \text { through fertilizer }\end{array}$ & $\begin{array}{l}100 \% \text { recommended (120:60:60) NPK } \\
\mathrm{kg} \mathrm{ha}^{-1} \text { through fertilizer }\end{array}$ \\
\hline$T_{6}$ & $\begin{array}{l}50 \% \text { NPK kg ha }{ }^{-1} \text { through fertilizer }+50 \\
\% \mathrm{~N} \text { through FYM }\end{array}$ & $\begin{array}{l}100 \% \text { recommended NPK kg ha } \\
\text { through fertilizer }\end{array}$ \\
\hline $\mathbf{T}_{7}$ & $\begin{array}{l}75 \% \text { NPK kg ha }{ }^{-1} \text { through fertilizer }+25 \\
\% \mathrm{~N} \text { through FYM }\end{array}$ & $\begin{array}{l}75 \% \text { recommended NPK kg ha } \\
\text { through fertilizer }\end{array}$ \\
\hline $\mathbf{T}_{8}$ & $\begin{array}{l}50 \% \mathrm{NPK} \mathrm{kg} \mathrm{ha}{ }^{-1} \text { through fertilizer }+50 \\
\% \mathrm{~N} \text { through what straw }\end{array}$ & $\begin{array}{l}100 \% \text { recommended NPK kg ha } \\
\text { through fertilizer }\end{array}$ \\
\hline $\mathbf{T}_{\mathbf{9}}$ & $\begin{array}{l}75 \% \text { NPK kg ha }{ }^{-1} \text { through fertilizer }+25 \\
\% \mathrm{~N} \text { through wheat straw }\end{array}$ & $\begin{array}{l}75 \% \text { recommended NPK kg ha } \\
\text { through fertilizer }\end{array}$ \\
\hline $\mathbf{T}_{10}$ & $\begin{array}{l}50 \% \mathrm{NPK} \mathrm{kg} \mathrm{ha}{ }^{-1} \text { through fertilizer }+50 \\
\% \mathrm{~N} \text { through green manuring (Glyricidia) }\end{array}$ & $\begin{array}{l}100 \% \text { recommended NPK kg ha } \\
\text { through fertilizer }\end{array}$ \\
\hline $\mathbf{T}_{11}$ & $\begin{array}{l}75 \% \mathrm{NPK} \mathrm{kg} \mathrm{ha}{ }^{-1} \text { through fertilizer }+25 \\
\% \mathrm{~N} \text { through green manuring (Glyricidia) }\end{array}$ & $\begin{array}{l}75 \% \text { recommended NPK kg ha } \\
\text { through fertilizer }\end{array}$ \\
\hline $\mathbf{T}_{12}$ & $\begin{array}{l}\text { Farmers practice }(40: 20: 20) \mathrm{NPK} \mathrm{kg} \mathrm{ha}{ }^{-1} \\
\text { and seed without carbofuron treatment }\end{array}$ & $\begin{array}{l}\text { Farmers practice (60:30:30) NPK kg } \\
\text { ha }^{-1} \text { and } 100 \mathrm{~kg} \mathrm{seed}^{-1}\end{array}$ \\
\hline$T_{13}$ & $\begin{array}{l}75 \% \text { NPK kg ha }{ }^{-1} \text { through fertilizer }+25 \\
\% \mathrm{~N} \text { through subabul leaves }\end{array}$ & $\begin{array}{l}75 \% \text { recommended NPK kg ha } \\
\text { through fertilizer }\end{array}$ \\
\hline$T_{14}$ & $\begin{array}{l}50 \% \mathrm{NPK} \mathrm{kg} \mathrm{ha}{ }^{-1} \text { through fertilizer }+50 \\
\% \mathrm{~N} \text { through subabul leaves }\end{array}$ & $\begin{array}{l}100 \% \text { recommended NPK kg ha } \\
\text { through fertilizer }\end{array}$ \\
\hline
\end{tabular}


Table.2 Long - Term Effect of Integrated Nutrient Management in Sorghum Wheat Cropping System on Humus fractions in soil

\begin{tabular}{|c|c|c|c|c|c|c|c|c|}
\hline \multirow{2}{*}{$\begin{array}{c}\text { Treatment } \\
\text { No. }\end{array}$} & \multicolumn{2}{|c|}{ Humin (\%) } & \multicolumn{2}{|c|}{ Humic acid (\%) } & \multicolumn{2}{|c|}{ Fulvic acid (\%) } & \multicolumn{2}{|c|}{ HA:FA ratio } \\
\hline & $\begin{array}{c}\text { 0-15 cm } \\
\text { Depth }\end{array}$ & $\begin{array}{c}15-30 \mathrm{~cm} \\
\text { Depth }\end{array}$ & $\begin{array}{l}\text { 0-15 cm } \\
\text { Depth }\end{array}$ & $\begin{array}{c}15-30 \mathrm{~cm} \\
\text { Depth }\end{array}$ & $\begin{array}{l}\text { 0-15 cm } \\
\text { Depth }\end{array}$ & $\begin{array}{c}15-30 \mathrm{~cm} \\
\text { Depth }\end{array}$ & $\begin{array}{l}\text { 0-15 cm } \\
\text { Depth }\end{array}$ & $\begin{array}{c}15-30 \mathrm{~cm} \\
\text { Depth }\end{array}$ \\
\hline $\mathbf{T}_{1}$ & 50.40 & 43.20 & 26.60 & 24.20 & 16.80 & 13.40 & 1.58 & 1.80 \\
\hline $\mathbf{T}_{2}$ & 49.50 & 40.20 & 27.40 & 25.20 & 17.80 & 13.90 & 1.53 & 1.81 \\
\hline $\mathbf{T}_{3}$ & 46.90 & 39.20 & 28.10 & 26.50 & 18.00 & 14.30 & 1.56 & 1.85 \\
\hline $\mathbf{T}_{4}$ & 48.00 & 40.20 & 27.80 & 26.20 & 18.10 & 14.90 & 1.53 & 1.75 \\
\hline $\mathbf{T}_{5}$ & 44.40 & 36.00 & 28.40 & 26.70 & 17.40 & 13.96 & 1.63 & 1.91 \\
\hline$T_{6}$ & 34.70 & 29.60 & 34.40 & 32.50 & 24.40 & 21.20 & 1.40 & 1.53 \\
\hline $\mathbf{T}_{7}$ & 39.40 & 31.30 & 28.40 & 26.50 & 22.50 & 20.40 & 1.26 & 1.29 \\
\hline $\mathbf{T}_{8}$ & 42.50 & 34.60 & 32.60 & 30.70 & 17.10 & 15.60 & 1.90 & 1.96 \\
\hline $\mathbf{T}_{9}$ & 43.80 & 35.20 & 29.70 & 27.40 & 17.70 & 15.50 & 1.87 & 1.76 \\
\hline $\mathbf{T}_{10}$ & 37.72 & 31.00 & 31.20 & 29.20 & 17.40 & 15.60 & 1.79 & 1.87 \\
\hline$T_{11}$ & 42.40 & 34.30 & 27.50 & 25.40 & 19.50 & 17.30 & 1.41 & 1.46 \\
\hline$T_{12}$ & 46.40 & 37.20 & 28.00 & 26.30 & 18.40 & 15.20 & 1.52 & 1.73 \\
\hline $\mathbf{T}_{13}$ & 41.20 & 32.60 & 28.30 & 26.70 & 18.20 & 16.10 & 1.55 & 1.65 \\
\hline$T_{14}$ & 38.90 & 30.30 & 32.50 & 29.90 & 21.20 & 19.00 & 1.53 & 1.57 \\
\hline S.E. \pm & 2.16 & 1.64 & 1.42 & 1.44 & 0.76 & 0.85 & 0.077 & 0.040 \\
\hline C.D. at $5 \%$ & 6.26 & 4.75 & 4.13 & 4.18 & 2.20 & 2.46 & 0.109 & 0.117 \\
\hline
\end{tabular}

Table.3 Correlation coefficient between physical-chemical properties of soil and soil organic carbon fraction

\begin{tabular}{|l|c|c|}
\hline \multicolumn{1}{|c|}{ Soil characteristics } & Organic carbon $\left(\mathbf{g ~ k g}^{-\mathbf{1}}\right)$ & Total carbon $\mathbf{( \mathbf { g ~ k g } ^ { - 1 } )}$ \\
\hline Bulk Density & $-0.533^{*}$ & $-0.584^{*}$ \\
\hline Porosity & $0.673^{* *}$ & $0.679^{* *}$ \\
\hline Water holding capacity & $0.747^{* *}$ & $0.826^{* *}$ \\
\hline pH & $-0.553^{*}$ & $-0.538^{*}$ \\
\hline $\mathbf{E C}$ & -0.172 & -0.286 \\
\hline $\mathbf{C a C O}$ & -0.235 & -0.190 \\
\hline
\end{tabular}

*Significant at $5 \%$ level $(0.532)$

**Significant at $1 \%$ level $(0.661)$

Table.4 Correlation coefficient between physico-chemical properties of soil and soil humus fraction

\begin{tabular}{|l|c|c|c|}
\hline \multicolumn{1}{|c|}{ Soil characteristics } & Humin (\%) & Humic acid (\%) & Fulvic acid (\%) \\
\hline Bulk Density & $0.579^{*}$ & $-0.578^{*}$ & 0.143 \\
\hline Porosity & $-0.533^{*}$ & $0.624^{*}$ & $-0.537^{*}$ \\
\hline Water holding capacity & -0.274 & $0.662^{* *}$ & -0.178 \\
\hline pH & $0.553^{*}$ & -0.473 & $0.570^{*}$ \\
\hline EC & -0.170 & -0.160 & 0.132 \\
\hline CaCO $_{3}$ & 0.160 & -0.371 & -0.070 \\
\hline
\end{tabular}

*Significant at $5 \%$ level $(0.532)$

**Significant at $1 \%$ level $(0.661)$ 


\section{Fulvic acid}

Fulvic acid content in $0-15 \mathrm{~cm}$ and $15-30 \mathrm{~cm}$ depth was varied from 16.80 to 24.40 precent and 13.40 to 21.20 percent, respectively (Table 2). The minimum fulvic acid content was recorded in control at surface soil and subsurface soil (16.80 and 13.40 percent respectively). While maximum fulvic acid content was observed in treatment $\mathrm{T}_{6}(24.40$ in surface layer and 21.20 in subsurface layer). Fulvic acid, although primarily considered to be humic acid degradation products as well.As per Naphade (1999) fulvic acid is important humus fraction that constitute organic matter. Similar observations were also reported by Meshram (2014) and Sangeeta (2015).

\section{HA: FA ratio}

The HA: FA ratio ranged in between 1.26 to $1.90 \%$ in $0-15 \mathrm{~cm}$ depth and 1.29 to $1.96 \%$ in $15-30 \mathrm{~cm}$ depth. The humic acid, fulvic acid ratio did not affect much due to application of inorganic fertilizers. The $\mathrm{T}_{8}$ treatment gave higher value of (1.90 and 1.96 in $-0-15$ and $15-30 \mathrm{~cm}$, respectively) of HA: FA ratio followed by $T_{9}$ and $T_{10}$ treatments as compared to other treatments (Table 2). The HA: FA ratio also varied significantly due to addition of organic manures and inorganic fertilizers alone.

Correlation coefficient between physicochemical properties of soil and soil organic carbon fraction

The data showed in Table $3 . \mathrm{CaCO}_{3}$ and EC content in soil did not showed significant correlation with organic carbon and total carbon. Further, it was indicated that porosity, WHC showed positive and significant correlation with organic carbon and total carbon which is indicated that by ' $r$ ' values of $0.673^{* *}, 0.679^{* *}, 0.747^{* *}$ and $0.826^{* *}$ respectively. The bulk density and $\mathrm{pH}$ showed negative and significant relation with organic carbon and total carbon which is noticed by ' $r$ ' value $\left(-0.533^{*}\right.$ and $\left.-0.553^{*}\right)$ similar findings were observed by Rudrappa et al., (2004) and Pal and shurpali (2006).

Correlation coefficient between physicochemical properties of soil a humus fraction

The data presented in Table 4. $\mathrm{CaCO}_{3}$ and $\mathrm{EC}$ content in soil did not showed significant correlation with Humin, Humic acid and Fulvic acid. Further, it was indicated that bulk density and water holding capacity showed positive and significant correlation with Humin and Humic acid, respectively which is indicated that by ' $r$ ' values of $0.579^{*}$ and $0.662 * *$, respectively. The $\mathrm{pH}$ showed positive and significant relation with Humic acid and Fulvic acid. Similar finding were also reported by Sangeeta (2015). The porosity showed negative and significant correlation with Humin and Fulvic acid and positive and significant relation with Humic acid.

In conclusion the long term effect of integrated nutrient management treatment under sorghum-wheat cropping sequence influenced the various forms of carbon and fractions of humus tended to decrease with depth and increase with initial value. Among the humus fractions studied indicated highest quantity of humin followed by humic acid and fulvic acid. $\mathrm{CaCO}_{3}$ and $\mathrm{EC}$ content in soil did not showed significant correlation with organic carbon and total carbon. Further, it was indicated that porosity, WHC showed positive and significant correlation with organic carbon and total carbon. The bulk density and $\mathrm{pH}$ showed negative and significant relation with organic carbon and total carbon. $\mathrm{CaCO}_{3}$ and $\mathrm{EC}$ content in soil did not showed significant correlation with 
Humin, Humic acid and Fulvic acid. Further, it was indicated that bulk density and water holding capacity showed positive and significant correlation with Humin and Humic acid. The $\mathrm{pH}$ showed positive and significant relation with Humic acid and Fulvic acid. The porosity showed negative and significant correlation with Humin and Fulvic acid and positive and significant relation with Humic acid.

\section{References}

Challa, O., Raman, K. V. and Raman, S. (1985). Studies on humic substances from forest soils of Tarai (foot-hills) region of Uttar Pradesh. Journal of the Indian Society of Soil Science.33: 5-10.

Gathala, M.K., Kanthaliya, P.C., Verma, A. and Chahar, M.S. (2007). Effect of integrated nutrient management on soil properties and humus fractions in the long- term fertilizer experiments. Journal of the Indian Society of Soil Science. 55 (3): 360-363.

Kharche, V. K., Patil, S. R., Kulkarni, A. A., Patil V. S. and Katkar, R. N. (2013). Long-term Integrated Nutrient Management for Enhancing Soil Quality and Crop Productivity under Intensive Cropping System on Vertisols. Journal of the Indian Society of Soil Science. Vol. 61(4): 323-332.

Malewar, G.U., Ramaswami, P.P. and Suseela Devi (1995). Status, nature, composition of soil organic matter in peninsular India. Journal of the Indian Society of Soil Science. 19: 48-57.

Meshram (2014). Influence of long-term organic manuring and inorganic fertilization under soybean-safflower cropping system on some soil quality indicators in vertisol. Ph.D. (Agri) Thesis, Dept. of SSAC, VNMKV, Parbhani (MS).

Naga Madhuri, K.V., Chandrasekara Rao, P.,
Prathima, T., Suresh, K., Vijay Krishna Kumar, K., and Giridhar V. (2013). Effect of long-term application of fertilizers on soil organic matter. International Journal of Applied Biology and Pharmaceutical Technology. 4 (2): 0976-4550.

Naphade, M. S. (1999). Characterization of humus under along term fertilization and manuring sorghum-wheat cropping system. M.Sc. (Agri) Thesis, Dept. of SSAC, MKV, Parbhani (MS).

Nguyen, T.H., Tanaka, M. and Shindo, H. (2010). Effect of long-term compost application on humus composition of whole soils and their particle size fractions in a field subjected mainly to double cropping. World Congress of Soil Science, Soil Solutions for a Changing world. pp: 79- 81.

Pal, S.S. and Shurpali, N. J. (2006). Variation in soil organic carbon as influenced by climate under different cropping system in India. Journal of the Indian Society of Soil Science. 54 (3): 294-299.

Rudrappa, L., Purakayastha, T.J., Singh Dhyanand Bhadraray, S. (2004). Longterm manurring and fertilization effect on soil organic carbon pools in a Typic Haplustep of semi-arid sub-tropical India. Soil and Tillage research 88: 180-192.

Sangeeta Medhi (2015). Studies on status of humus under long-term fertilization in sorghum-wheat cropping sequence in Vertisols. M.Sc. Agri Thesis, Vasantrao Naik Marathwada Agricultural University, Parbhani (MS).

Stevenson, F.J. (1982). Organic forms of soil nitrogen. In nitrogen in agricultural soils (F.J. Stevenson, Ed) American Society of Agronomy and Soil Science Society of America, Madison, WI.

Technical manual U.S.E.P.A. (2001). Methods for collection, storage and manipulation of sediments for chemical 
and toxicological Analysis: Technical manual U.S. Environmental Protection Agency Washington. D.C. 204-260.

Vijay Shankar Babu, M., Mastan Reddy, C., Subramanyana, A. and Balaguraravaiah, D. (2007). Effect of integrated use of organic and inorganic fertilizers on soil properties and yield of Sugarcane. Journal Indian society soil science. 55:
161-166.

Waikar, S. L., Malewar, G. U., More, S. D. and Kausadikar, H. K. (2004). Humic substances and functional groups of soil humus reserve developed under varied agroclimatic units of South-Central part of Maharashtra. J. Indian Soc. Soil Sci., 52(2): 147-150.

\section{How to cite this article:}

Dhamak, A. L., S. L. Waikar and Shilewant, S. S. 2020. Characterization of Humus in Soil and It's Relation with Physical and Physic-Chemical Properties of Soil Under Long - Term Effect of Integrated Nutrient Management in Sorghum Wheat Cropping System. Int.J.Curr.Microbiol.App.Sci. 9(10): 561-568. doi: https://doi.org/10.20546/ijcmas.2020.910.067 